Abstracta Iranica Iranica

Revue bibliographique pour le domaine irano-aryen

Volume 40-41 | 2019

Comptes rendus des publications de 2017-2018

\title{
Françoise Briquel-Chatonnet, Muriel Debié. Le Monde syriaque. Sur les routes d'un christianisme ignoré
}

Florence Jullien

\section{OpenEdition}

\section{Édition électronique}

URL : http://journals.openedition.org/abstractairanica/50971

DOI : 10.4000/abstractairanica.50971

ISBN : 1961-960X

ISSN : 1961-960X

Éditeur :

CNRS (UMR 7528 Mondes iraniens et indiens), Éditions de l'IFRI

Référence électronique

Florence Jullien, «Françoise Briquel-Chatonnet, Muriel Debié. Le Monde syriaque. Sur les routes d'un christianisme ignoré », Abstracta Iranica [En ligne], Volume 40-41 | 2019, document 22, mis en ligne le 30 décembre 2019, consulté le 17 avril 2021. URL : http://journals.openedition.org/abstractairanica/ 50971 ; DOI : https://doi.org/10.4000/abstractairanica.50971

Ce document a été généré automatiquement le 17 avril 2021.

Tous droits réservés 


\title{
Françoise Briquel-Chatonnet, Muriel Debié. Le Monde syriaque. Sur les routes d'un christianisme ignoré
}

\author{
Florence Jullien
}

\section{RÉFÉRENCE}

Françoise Briquel-Chatonnet, Muriel Debié. Le Monde syriaque. Sur les routes d'un christianisme ignoré. Paris : Les Belles Lettres, 2017, 272 p. ISBN 978-2251447155

1 Cet ouvrage a d'abord vocation à vulgariser auprès d'un large public 2000 ans d'histoire et de culture syriaques. Cette forme d'araméen, née de contacts à la frontière des empires romain et parthe, est à côté du latin et du grec la troisième composante du christianisme ancien. Avec la christianisation, le syriaque a connu un développement exceptionnel et s'est développé vers l'est, de la Méditerranée à l'Asie orientale jusqu'en Inde et en Chine. Il constitue aujourd'hui encore la langue classique, littéraire et religieuse de plusieurs Églises orientales. Huit chapitres chronologico-thématiques permettent d'effectuer ce parcours historique : les origines de la culture syriaque dans le berceau édessénien; l'expansion du christianisme en mondes romain et perse jusqu'au IV ${ }^{e}$ s.; le monachisme syriaque oriental et occidental et son rôle dans les économies locales et la diffusion des savoirs; les développements de l'écriture et les milieux scholastiques; les mouvements missionnaires ad extra et les réseaux routiers ; la période des autonomisations et des séparations théologiques, et la continuité dans la transmission des savoirs jusqu'à la période abbasside incluse $\left(\mathrm{V}^{\mathrm{e}}-\mathrm{IX}^{\mathrm{e}} \mathrm{s}\right.$.) ; enfin les $\mathrm{X}^{\mathrm{e}}$ $\mathrm{XIV}^{\mathrm{e}} \mathrm{s}$. sur les traditions et nouvelles influences, et les $\mathrm{XV}^{\mathrm{e}}-\mathrm{XIX}^{\mathrm{e}} \mathrm{s}$. sur les interactions avec l'Occident : uniatisme, missions occidentales et identités, génocide et diasporas. Un glossaire, une annexe sur les diverses confessions christologiques des Églises syriaques, une brève chronologie, un index et une sélection bibliographique viennent clore l'ouvrage. Le lecteur apprécie tout spécialement la citation de textes de diverses 
époques en encarts ainsi que les nombreuses illustrations et cartes à l'appui du propos. Cet ouvrage contribuera à mieux faire connaître une culture encore trop ignorée.

\section{AUTEURS}

\section{FLORENCE JULLIEN}

CNRS, Mondes iranien et indien, Paris 